\title{
Êxtase e Metrópole
}

Săo Paulo nasce sob a égide do movimento, da violência e da velocidade. Até atingir seu cúmulo, esse hoje gigante caleidoscópio que não cessa de girar, erguia-se já lá, como urbanidade transtornada. Tornou-se visível nos acontecimentos cotidianos que tomavam e desinstalavam indivíduos aglomerados e extasiados diante da fremência das festas de carnavais ou da inesperada calamidade de uma enchente. Orfeu extático na Metrópole de Nicolau Sevcenko (Companhia das Letras, 390 páginas), percorrendo a São Paulo dos anos 20 , compõe sobretudo uma galeria móvel de sentidos e de planos de enunciação que dão lugar a uma certa forma de metropolização.

Orfeu extático está desenvolvido em três partes, compondo três formas de narrar a história do surgimento da metrópole paulistana. Da urbanização acelerada, passando pelo contato impactante e conflitivo com a força da cultura européia, Sevcenko expōe as fraturas do cenário da modernidade paulista - tão empenhada em novas possibilidades de criação, quanto assujeitada à hegemonia cultural de movimentos europeus e aos novos modelos de tecnologia emergente.

A linguagem que funciona na textura dessa obra abre espaço para múltiplas perspectivas e interpretações. Sevcenko põe-se à vontade cruzando falas e estilos. A crônica jornalistica reconstitui o cotidiano de uma multidão fragmentada diante das vicissitudes dos fenômenos factuais pequenas grandes tragédias compartilhadas por olhos coletivos. Mas não apenas isso. Há, nos diferentes modos de narrar acontecimentos rotineiros, um efeito de imersão e contemplação.

Ao introduzir, em sua narrativa, o ponto de vista de dois diferentes cronistas de um jornal diário, o autor os define quase que como reimpressões do mito de oríeu. Sevcenko chama de $S$. e $P$. aos cronistas, nos quais se apóia para narrar o nascimento, não só de uma certa urbani- 
dade, mas das modalidades diversas de estar nela. Tais modalidades são também parte do aparecimento dessa mesma urbanidade..

Diz o autor desse livro que "se a experiência de $S$. é de se unir, de se integrar às legiōes de estranhos, a de $P$. é de observálos (...); se o que $\mathbf{S}$. busca ao juntar-se à multidão é a excitação de tornar-se algo diferente de si mesmo, um corpo gigantesco e poderoso, $\mathbf{P}$., por sua vez, também encontra excitação ao reduzir a multidão com seu olhar perscrutrador ao mais completo grau de estranhamento". É nesse efeito de estranhamento, dado pela técnica narrativa, que Sevcenko entrevê uma das fundamentais condições da metropolização.

Por certo, a evocação do mito de orfeu remete Sevcenko ao caráter da incompletude como traço singular do processo histórico de metropolização derivado de uma aldeia jesuítica, assentada no alto da Serra do Mar para fins catequéticos. "A grande surpresa foi que São Paulo viesse a existir", diz Sevcenko. Plantada sobre um solo lodoso, que expunha seus habitantes a uma vida precária, entregue a doenças e pobreza, nada fazia supor, escreve o historiador, que aquele nicho de expiação cristã abrigava o campo de proveniência de uma grande metrópole. Sevcenko ressalta o signo da aceleração, sob o qual, mediante $o$ incremento econômico da lavoura cafeeira, emergiram as circunstâncias que deram existência a essa megalópole. $\mathrm{O}$ efeito estimulante e narcotizante de uma toxina não cessou de funcionar nas múltiplas enunciações que designam São Paulo como a cidade que mais cresce no mundo.

Pedro de Souza

Rua, Campinas, 1:143-144, 1995 